\begin{tabular}{|c|c|c|}
\hline \multirow{3}{*}{$\begin{array}{l}\text { EREM 76/4 } \\
\text { Journal of Environmental Research, } \\
\text { Engineering and Management } \\
\text { Vol. } 76 \text { / No. } 4 \text { / } 2020 \\
\text { pp. } 20-31 \\
\text { DOl 10.5755/j01.erem.76.4.27536 }\end{array}$} & \multicolumn{2}{|c|}{$\begin{array}{l}\text { Bioeconomy as One of the Key Areas of Implementing } \\
\text { a Circular Economy (CE) in Poland }\end{array}$} \\
\hline & Received 2020/08 & Accepted after revision 2020/11 \\
\hline & \multicolumn{2}{|c|}{ crossef http://dx.doi.org/10.5755/j01.erem.76.4.27536 } \\
\hline
\end{tabular}

\title{
Bioeconomy as One of the Key Areas of Implementing a Circular Economy (CE) in Poland
}

\author{
Paulina Marcinek*, Marzena Smol \\ Mineral and Energy Economy Research Institute, Polish Academy of Sciences, \\ Wybickiego 7A str., 31-261 Cracow, Poland
}

*Corresponding author: marcinek@meeri.pl

Transformation toward a circular economy (CE) model is one of the main priorities of the European Commission (EC). In the previous years, most of the European countries prepared national documents presenting their possibilities and plans for implementing CE in the country. In Poland, in 2019, the CE roadmap was approved by the government. Bioeconomy was indicated in this document as one of the key areas of CE implementation in Poland. This paper presents a detailed review of the actions needed for the transformation toward the CE model in Poland, and the units responsible for their implementation in the bioeconomy sector. The most important actions include creating conditions for the development of bioeconomy and building local value chains and a raw material base. Moreover, actions in the energy sector and transformation of industry is also indicated. Poland places great emphasis on strengthening cooperation between industry and the science sector, which should contribute to the implementation of innovative solutions in the whole economy, including bioeconomy. Therefore, it is necessary to integrate all activities taken by various stakeholders and the government at the central, regional and local level. A great opportunity to further development of bioeconomy in Poland is large resources of biomass in country. An increase in the biomass usage can positively accelerate the transformation process towards CE. Further efforts are required and planned in this area, based on the directions indicated in the Polish CE roadmap.

Keywords: bioeconomy, circular economy (CE), European Union (EU), Polish CE roadmap. 


\section{Introduction}

Nowadays, many countries and regions of the world, including European ones, are in the process of transformation towards a circular economy (CE) which can be indicated as an irreversible global trend. On the European level, the CE was indicated as the priority economic policy of the European Union (EU) in 2014 (COM no. 398, 2014)paleoclimate archives, theoretical studies of climate processes and simulations using climate models. It builds upon the Working Group I contribution to the IPCC's Fourth Assessment Report (AR4. Then in 2015, the first CE Action Plan was published (COM no. 614, 2015), which was implemented by the end of 2019. Currently, the new CE Action Plan is in force, and it was published in 2020 (COM no. 98, 2020). To stimulate the transformation process, the European Commission (EC) recommended the Member States to prepare road maps setting specific goals of the $C E$ at the national levels (Smol et al., 2020)especially in the transformation process towards a circular economy (CE. Many of the European countries already developed and adopted the CE roadmaps, including Netherlands, France, Germany, Finland, Spain, or Poland. Most of the national CE roadmaps are published on the website of the European Circular Economy Stakeholders Platform, which supports the CE implementation in Europe (ECESP, 2020).

At the same time, the EC emphasizes the role of the bioeconomy in the provisions regarding the transition from the linear to the circular model. It should be pointed that activities in the field of bioeconomy were undertaken earlier at the European level, including dedicated strategy for bioeconomy from 2012 (COM no. 60,2012 ), which contains the most important tasks to be performed in this area, as creating a resource-efficient, innovative and competitive society, ensuring food security; sustainable use of biological resources, and creating a coherent political environment. In 2014, the bioeconomy was officially included as a part of CE implementation in the EU (COM no. 398, 2014)paleoclimate archives, theoretical studies of climate processes and simulations using climate models. It builds upon the Working Group I contribution to the IPCC's Fourth Assessment Report (AR4, and the postulates in the first CE Action Plan associated with rational waste management, sustainable resources management, increasing the competitiveness of the Member States in the world, supporting sustainable economic growth and creating new jobs (COM no. 614, 2015), can also be considered as implementation paths of the bioeconomy strategy (COM no. 60, 2012). Further activities in this area are continued, as assumes the new CE Action Plan (COM no. 98,2020 ).

Most of the European countries place great emphasis on the bioeconomy, which can be defined as the economy where the most important components of production - materials, energy and chemical products - are based on biological and renewable resources (McCormick and Kautto, 2013). It makes it possible to convert bio-waste, leftovers and discards into valuable resources as well as create innovation and encourage retailers and consumers to reduce food waste. Because the bioeconomy is a very important element of the CE implementation, it was also indicated in the developed national CE roadmaps. One of the countries which specifies the bioeconomy as the key area in the transformation towards CE is Poland, which in 2019 presented an official document approved by the government "Roadmap for transformation towards a circular economy" (Polish Roadmap, 2019). The current paper presents a review of the most important actions needed for the implementation of the CE assumptions in the bioeconomy, which were indicated in the Polish CE roadmap. Moreover, an analysis of the available sources of biomass, which is the most important renewable resource in Poland, is presented and results are discussed.

\section{Methods}

The research analysis conducted in this article was based on an in-depth review of the literature using a desk research method. The research used strategic documents related to the implementation of the bioeconomy and the circular economy in the Member States, and thus the implementation of sustainable development (SD) in their areas. Numerous legal communications directly related to the bioeconomy and the CE were revised. Moreover, peer-reviewed articles (published on scientific platforms) related to the mentioned topics were also reviewed. The selection of the analyzed 
literature was based on the following key words: bioeconomy, green economy, circular economy, CE, sustainable development, SD, CE roadmaps. It should be emphasized that during the initial analysis, several hundred literary items were obtained. This is due to the fact that the bioeconomy and the above-mentioned aspects were described in many other publications not only in Europe, but also around the world, and for several years there has been an increase in bioeconomy and CE issues. For this reason, attempts were made to select publications the content of which is still relevant, and the evolving definitions of the same aspect - bioeconomy - were compiled for better understanding.

Currently, there are no indicators in Poland that would directly reflect the development of the bioeconomy in the country. However, there are measures describing activities for the environment in such areas as: natural capital, environmental efficiency of production, environmental quality of people's life, economic policy and their consequences. An analysis of selected indicators was carried out with the use of data obtained from the Central Statistical Office in Poland to obtain information on activities aimed at supporting the natural environment.

Finally, the results of the study and directions of bioeconomy development were interpreted. The acquired information and previous knowledge were combined and gave valuable conclusions.

\section{Results and Discussion}

\section{Bioeconomy - definitions}

Bioeconomy is a concept or a strategy that answers the growing demand for the development of science in the field of new regulations and processes in the economy. A comprehensive nature of bioeconomy has contributed to the fact that it can be defined depending on the area it covers. The choice of the right definition - the approach and its components - directly influences the specification of the policy, programs and strategies for economic development (Maciejczak and Hofreiter, 2013). The list of the available bioeconomy definitions is presented in Table 1.

As seen from Table 1, there are many definitions of bioeconomy resulting from different approaches. Over the years, the definition has been changed, specified and enriched with new information. The first attempts to define the bioeconomy were made at the end of the $19^{\text {th }}$ century, and their dynamic development began in 2007 (Adamowicz, 2017). While creating the definition of the bioeconomy, certain regularities can be noticed, consisting in moving from general, simple concepts based on the management of renewable energy sources to more complex and adapting to the conditions prevailing in a given country and the needs of bioeconomy analysis. The EU institutions, mainly the Organisation for Economic Co-operation and Development (OECD) and the USA institutions, have a key impact on the development of the bioeconomy. There are some differences between the concepts of bioeconomy in European countries and the United States. First of all, they differ, inter alia, in that the concept of the USA bioeconomy often does not take into account traditional agriculture. The cross-sectoral character of bioeconomy influences the consideration of this strategy from the point of view of innovation and economic benefits resulting from its development. It is recommended that countries promote and support bioeconomy and set up appropriate institutions for this purpose for better management of this strategy (Adamowicz, 2017). There was an evolutionary path leading to the current definition of bioeconomy, from the original version of the definition formulated by Juan Enriquez and Rodrigo (Enriquez, 1998), which initiated interest in bioeconomy of the EU bodies, through a number of EU definitions enriched with newer information and the OECD definition from 2009 (OECD, 2009) to a more developed definition formulated by the European Commission in 2012 (COM no. 60,2012$)$, which was modernized and tidied up in 2018 (COM no. 673, 2018). The dissemination of various versions of the definition of bioeconomy was facilitated by numerous organizations, national and international institutions that deal with the conduct and implementation of advanced scientific research.

One of the earliest bioeconomy definitions was provided by Enriquez and Martinez as an economic activity based on research and implementation that focuses on understanding processes and mechanisms at the molecular level aimed at applying them to specific industrial processes (Martinez, 1998). The dynamically developing natural sciences meant that the concept of bioeconomy gained more and more interested people. The special 
Table 1. The bioeconomy definitions

\begin{tabular}{|c|c|c|}
\hline $\begin{array}{l}\text { Date of } \\
\text { publication }\end{array}$ & Description & Source \\
\hline 1997 & $\begin{array}{l}\text { business activities based on scientific research and implementations focused on understanding } \\
\text { mechanisms and processes at the genetic level to apply them in industrial processes }\end{array}$ & $\begin{array}{l}\text { Enriquez and } \\
\text { Martinez }\end{array}$ \\
\hline 2005 & $\begin{array}{l}\text { bioeconomy is an environmentally friendly, eco-efficient transformation of renewable resources } \\
\text { into food, energy or other industrial products }\end{array}$ & DG Research \\
\hline 2006 & $\begin{array}{l}\text { all production systems that use biochemical and biophysical processes, including all natural sciences } \\
\text { and related technologies used and necessary for the production of products; bioeconomy also cov- } \\
\text { ers: bio-refineries, bioenergy and biochemicals generation, pioneering forms of land and sea use for } \\
\text { the production of public goods and the use of materials that are commonly considered waste }\end{array}$ & DG Research \\
\hline 2007 & production of food, bioproducts and bioenergy from biological resources & Cologne Paper \\
\hline 2007 & $\begin{array}{l}\text { economic activity capturing value hidden in renewable bio-resources and biological processes, } \\
\text { which contributes to improving health, growth and development of environmentally friendly eco- } \\
\text { nomic activity capturing hidden in renewable processes }\end{array}$ & DEFRA \\
\hline 2009 & $\begin{array}{l}\text { bioeconomy is the exchange of knowledge (resulting from natural sciences) for new, friendly, en- } \\
\text { vironmentally safe, eco-efficient and competitive products }\end{array}$ & OECD \\
\hline 2010 & any sector that produces its biomass-based products & BECOTEPS \\
\hline 2010 & $\begin{array}{l}\text { the production model, which is based on biological processes, uses natural materials, consumes } \\
\text { minimal amounts of energy and also does not generate waste, since discards created in one pro- } \\
\text { cess become material for the next and thus are reused in the ecosystem }\end{array}$ & $\begin{array}{l}\text { European } \\
\text { Commision }\end{array}$ \\
\hline 2011 & $\begin{array}{l}\text { environmentally friendly and safe production processing of biomass for the production of food, } \\
\text { textile, health, industrial and energy }\end{array}$ & EPSO \\
\hline 2013 & $\begin{array}{l}\text { an economy in which the most important components of production - the production of materials, } \\
\text { energy and chemical products - are based on biological and renewable resources }\end{array}$ & $\begin{array}{l}\text { McCormick } \\
\text { and Kautto }\end{array}$ \\
\hline 2011 & $\begin{array}{l}\text { bioeconomy is based on natural resources, which include animal and vegetable raw materials as } \\
\text { well as microorganisms }\end{array}$ & $\begin{array}{l}\text { Chyłek and } \\
\text { Rzepecka }\end{array}$ \\
\hline 2012 & $\begin{array}{l}\text { making use of scientific research and innovation in the natural sciences, and generating social } \\
\text { benefits and stimulating economic activity }\end{array}$ & $\begin{array}{l}\text { The White } \\
\text { House }\end{array}$ \\
\hline 2012 & $\begin{array}{l}\text { bioeconomy covers the functions and principles of all systems and sectors that operate based on } \\
\text { biological resources (animals, plants, microorganisms, biomass, organic waste). Thus, its basic } \\
\text { function is to build added value using biological renewable resources; covers terrestrial and ma- } \\
\text { rine ecosystems, the forestry, agriculture and food sectors, as well as pulp and paper production; } \\
\text { bioeconomics also applies to parts of the biotechnology, chemical and energy industries }\end{array}$ & $\begin{array}{l}\text { European } \\
\text { Commision }\end{array}$ \\
\hline 2013 & a set of sectors dealing with the production, processing and use of biological resources & Gołębiewski \\
\hline 2018 & $\begin{array}{l}\text { bioeconomy applies to all sectors and systems that use biological resources (microorganisms and } \\
\text { biomass (also organic waste), plants, animals), their principles and functions; combines terrestri- } \\
\text { al and marine environment, provides services, all sectors of primary production using biological } \\
\text { resources for production (aquaculture, fisheries, agriculture and forestry); all sectors of industry } \\
\text { and economy which use biological resources for their purposes (production of feed, food, energy } \\
\text { or services); a properly functioning European economy should be based on a circular economy and } \\
\text { sustainable development (SD), which will contribute to industry, modernizing primary production } \\
\text { systems, protecting the environment and increasing biodiversity }\end{array}$ & $\begin{array}{l}\text { European } \\
\text { Commision }\end{array}$ \\
\hline
\end{tabular}


attention was paid to the link between the bioeconomy and the natural environment, which was identified with the link between ecodevelopment and sustainable development. Other definition from 2005 described bioeconomy as an ecoefficient and environmentally friendly transformation of renewable resources into food, energy or other industrial products (DG Research, 2005). Proceeding analogously, in 2006, Directorate-General for Research (DG Research) developed its new concept and indicated that the bioeconomy refers to all production systems using biophysical and biochemical processes, including the natural sciences and related technologies that are generally used and are essential elements needed to produce useful products, not forgetting the biotechnological processes used in industry and agriculture. The bioeconomy also covers biorefineries, the production of biochemicals, the production of bioenergy and the innovative use of the marine and land environment for the production of goods, as well as the use of materials that are commonly considered waste (DG Research, 2006). It should be also pointed that countries with well-developed agriculture and large biological resources recognized the importance the development of the bioeconomy in the last two decades. In 2007, a conference was organized ("En Route to the Knowledge-Based Bio-Economy") at which it was announced that the bioeconomy is the production and processing of renewable biological resources, among others for food, bioenergy and biobased products (Cologne Paper, 2007). In the same year, Department of Environment Food and Rual Affairs (DEFRA) defined the concept of bioeconomy as an economic activity that captures hidden value in biological processes, which improves health and increases environmentally friendly development (DEFRA, 2007). In 2009, the OECD expressed its opinion on the bioeconomy, classifying it as an eco-efficient change of existing knowledge resulting from life sciences in favor of innovative, safe and environmentally friendly eco-efficient and competitive products (OECD, 2009). Developing this concept, the OECD identified three elements that the bioeconomy covers. Those are:

development of innovative products and processes using specialized knowledge in the field of genes and cellular processes,

stimulation of sustainable production using biomass and bioprocesses, enabling the application of biotechnology in many sectors through its integration.

Since 2010, more and more dynamic development and dissemination of the concept of bioeconomy have been noticed, among others with the support of EU bodies. According to the BECOTEPS platform, the bioeconomy areas include all sectors where products are derived from biomass (BECOTEPS, 2010). The document "Bioeconomy for Europe" prepared by the EC in 2010 presents models that are based on biological processes occurring in natural ecosystems. In these processes, minimal amounts of energy are used to process natural materials without generating waste, because the rejects generated in one process are the material in the next and are therefore still used in circulation (EC, 2010). The bioeconomy was similarly defined in the EU document "The European Bioeconomy in 2030. Delivering Sustainable Growth by addressing the Grand Societal Challenges" from 2011, which characterized it as a safe and environmentally friendly production in which biomass is processed for food, health, textiles, industry and energy (EPSO, 2011). The bioeconomy definitions in the United States, despite a few differences, are very similar to those created by the OECD in the EU. A document "National Bioeconomy Blueprint", published by the White House in 2012, provides information about the bioeconomy as an economy based on research and innovation in life sciences that generate benefits and stimulate economic activity (The White House, 2012). The United States of America (USA) pays particular attention to biofuels, industrial biotechnology, the chemical industry, transport and recycling. These areas fall under the so called "gray bioeconomy" (Adamowicz, 2017). One of the most precise definitions of bioeconomy is the one created in 2012, which emphasizes that bioeconomy is all systems and sectors in which activities are based on biological resources (animals, plants, microorganisms, biomass, organic waste). For this reason, its primary function is to create added value using biological renewable resources, and its activities include terrestrial and marine ecosystems, agriculture, forestry, the food sector, as well as the production of paper and pulp. Bioeconomy is also used in some of the biotechnology, chemical and energy industries (COM no. 60, 2012). Bioeconomy has also been defined as the economy in which the main production components, such as the production of materials 
and chemical products are based on renewable and biological resources, in which biotechnology is an important factor influencing economic development (McCormick and Kautto, 2013). Currently, the most extensive and comprehensive definition is the one formulated in 2018 by the EC, which supplemented the document from 2012 (COM no. 60, 2012). It was stated that "bioeconomy covers all sectors and systems that rely on biological resources (animals, plants, micro-organisms and derived biomass, including organic waste), their functions and principles. It includes and interlinks: land and marine ecosystems and the services they provide; all primary production sectors that use and produce biological resources (agriculture, forestry, fisheries and aquaculture); and all economic and industrial sectors that use biological resources and processes to produce food, feed, bio-based products, energy and services" (COM no. 673, 2018).

In Poland, the definition of the bioeconomy was proposed by several authors and organizations. The idea of bioeconomy is defined in a different way in Poland, due to various approaches to this topic. Starting from the definition characterizing the bioeconomy as a way to achieve a society independent of fossil fuels, used in energy production as well as industrial products (Bartoszczuk, 2014) to more general statements that the basic function of bioeconomy is to use renewable resources in a sustainable and environmentally safe manner while maintaining innovation and transforming the acquired resources into desired products (Maciejczak and Hofreiter, 2013). Some of the Polish scientists claim that the bioeconomy is based on natural resources, which include raw materials of plant and animal origin, and microorganisms (Chytek and Rzepecka, 2011). Others claim that it is a set of sectors that deal with the production, processing and use of biological resources (Gołębiewski, 2013). Nevertheless, all these definitions have a common feature - they refer to biomass, which includes all kinds of organic substances (animal, plant), as well as all products obtained as a result of processing raw materials (e.g., trees, manure, sewage sludge, straw) (Kowalik, 2003). The Polish government defined bioeconomy in the Polish Roadmap: "bioeconomy presupposes the management of renewable resources in an optimal, responsible and sustainable way. This means that these resources should be used in the most economically and environmentally beneficial way, taking into account the principle that food is the most important product. In addition, they should be managed in such a way as to ensure that resources, including soil, surface water and air, are fully recoverable" (Polish Roadmap, 2019). Moreover, in the Polish roadmap, the circular bioeconomy is indicated as a biological cycle in the economy, which is one of the two main pillars of the CE (next to the technological cycle). The biological cycle focuses on the management of renewable resources, as biomass, taking into account their overall life cycle. The Polish CE roadmap focuses on general activities related to creating conditions for the bioeconomy and proceedings focused on key areas, which are creating local value chains, industry and energy. In addition, the bioeconomy also has effects in reducing pressure on the environment, reducing greenhouse gas emissions, primarily carbon dioxide $\left(\mathrm{CO}_{2}\right)$ and methane $\left(\mathrm{CH}_{4}\right)$ and creating new jobs, especially in rural areas.

\section{Importance of bioeconomy in the transition to the CE model in Poland}

Bioeconomy is indicated in the CE roadmap as one of the key areas of the CE implementation in Poland. The other key areas are sustainable industrial production, sustainable consumption, new business models, and monitoring and financing of CE. In the area of bioeconomy, the roadmap specifies the priority actions which have to be taken in the coming years, as:

actions in the field of creating conditions for the development of bioeconomy,

actions in the area of building local value chains and raw material base,

actions in the area of energy,

actions in the area of industry.

Poland places great emphasis on strengthening cooperation between industry and the science sector, which will contribute to the implementation of innovative solutions in the whole economy, including bioeconomy. Therefore, it is necessary to integrate the indicated activities as well as tighten cooperation between various stakeholders and the government at the central, regional and local level. Actions aimed at supporting the development of bioeconomy in Poland and the ministries responsible for their implementation are summarized in the diagram below (Table 2). 
Table 2. Actions supporting the development of bioeconomy in Poland and the ministries responsible for their implementation (Polish Roadmap, 2019)

\begin{tabular}{|c|c|c|c|}
\hline Action area & Action & Competent agency & Timetable \\
\hline \multirow{4}{*}{$\begin{array}{l}\text { Creating conditions } \\
\text { for the develop- } \\
\text { ment of bioecon- } \\
\text { omy }\end{array}$} & $\begin{array}{l}\text { establish a permanent team of department di- } \\
\text { rectors at government agencies responsible for } \\
\text { individual areas of bioeconomy and appointing } \\
\text { a coordinator in charge of defining the develop- } \\
\text { ment directions for bioeconomy, supervising the } \\
\text { implementation of tasks in individual areas and } \\
\text { improving the flow of information between these } \\
\text { agencies }\end{array}$ & $\begin{array}{l}\text { the Ministry of Development in coopera- } \\
\text { tion with the Ministry of Agriculture and } \\
\text { Rural Development, the Ministry of En- } \\
\text { vironment, the Ministry of Science and } \\
\text { Higher Education, the Ministry of Ener- } \\
\text { gy, the Ministry of Maritime Economy } \\
\text { and Inland Navigation }\end{array}$ & $2019-2020$ \\
\hline & $\begin{array}{l}\text { review of existing regulations and development } \\
\text { of uniform requirements/standards for biomass }\end{array}$ & $\begin{array}{l}\text { the Ministry of Environment in cooper- } \\
\text { ation with the Ministry of Development, } \\
\text { the Ministry of Energy and the Ministry } \\
\text { of Agriculture and Rural Development }\end{array}$ & $2021-2022$ \\
\hline & $\begin{array}{l}\text { analysis of biomass supply potential at the na- } \\
\text { tional and regional level, preceded by the devel- } \\
\text { opment of an appropriate methodology }\end{array}$ & $\begin{array}{l}\text { the Ministry of Agriculture and Rural De- } \\
\text { velopment in cooperation with the Min- } \\
\text { istry of Environment and the Ministry of } \\
\text { Maritime Economy and Inland Navigation }\end{array}$ & $2021-2022$ \\
\hline & $\begin{array}{l}\text { identification of research, development and inno- } \\
\text { vation }(R \& D \& I) \text { priorities for the development of } \\
\text { bioeconomy in Poland }\end{array}$ & $\begin{array}{l}\text { the Ministry of Science and Higher Edu- } \\
\text { cation in cooperation with the Ministry of } \\
\text { Economy and the Ministry of Agriculture } \\
\text { and Rural Development }\end{array}$ & $2021-2022$ \\
\hline \multirow{3}{*}{$\begin{array}{l}\text { Building local value } \\
\text { chains and raw } \\
\text { material base }\end{array}$} & identifying local value chain & $\begin{array}{l}\text { the Ministry of Economy in cooperation } \\
\text { with the Ministry of Agriculture and Ru- } \\
\text { ral Development }\end{array}$ & $2011-2022$ \\
\hline & $\begin{array}{l}\text { feasibility study on the creation and development } \\
\text { of local biorefineries }\end{array}$ & $\begin{array}{l}\text { the Ministry of Development in coopera- } \\
\text { tion with the Ministry of Energy }\end{array}$ & $2021-2023$ \\
\hline & $\begin{array}{l}\text { information campaign aimed at educating farm- } \\
\text { ers and targeting their activities on CE }\end{array}$ & $\begin{array}{l}\text { the Ministry of Agriculture and Rural De- } \\
\text { velopment }\end{array}$ & $2020-2021$ \\
\hline \multirow[t]{2}{*}{ Energy } & $\begin{array}{l}\text { information campaign on the principle of cas- } \\
\text { cading use of biomass }\end{array}$ & $\begin{array}{l}\text { the Ministry of Agriculture and Rural De- } \\
\text { velopment in cooperation with the Min- } \\
\text { istry of Environment }\end{array}$ & $2020-2021$ \\
\hline & $\begin{array}{l}\text { analysis of barriers to the use of advanced bio- } \\
\text { fuels in transport }\end{array}$ & $\begin{array}{l}\text { the Ministry of Energy in cooperation } \\
\text { with the Ministry of Infrastructure }\end{array}$ & 2023 \\
\hline \multirow{4}{*}{ Industry } & information campaign on biomass products & $\begin{array}{l}\text { the Ministry of Economy in cooperation } \\
\text { with the Ministry of Agriculture and Ru- } \\
\text { ral Development }\end{array}$ & $2020-2021$ \\
\hline & $\begin{array}{l}\text { drawing up norms and standards for particular } \\
\text { categories of products made from biomass }\end{array}$ & $\begin{array}{l}\text { the Ministry of Economy in cooperation } \\
\text { with the Ministry of Agriculture and Ru- } \\
\text { ral Development }\end{array}$ & 2019-2023 \\
\hline & $\begin{array}{l}\text { developing a concept for an information platform } \\
\text { on current quantity, quality, place and source } \\
\text { (agriculture, forestry, fisheries, bio - waste) of } \\
\text { biomass }\end{array}$ & $\begin{array}{l}\text { the Ministry of Agriculture and Rural } \\
\text { Development in cooperation with the } \\
\text { Ministry od Digitalization, the Ministry } \\
\text { of Environment, the Ministry of Mari- } \\
\text { time Economy and Inland Navigation } \\
\text { and the Central Statistical Office }\end{array}$ & $2021-2023$ \\
\hline & $\begin{array}{l}\text { establishment of a working group with entrepre- } \\
\text { neurs to develop the concept and creation of a } \\
\text { cluster for bio - economic development }\end{array}$ & the Ministry of Economy & $2019-2020$ \\
\hline
\end{tabular}


Poland does not have one department responsible for shaping and setting the framework, and directions of bioeconomy development. This is due to the cross-sectional and intersectoral nature of the bioeconomy. Individual areas of renewable resources management are within the competence of many development, which hinders coordination of activities and creating a stable framework for the development of bioeconomy, which currently has a high priority in the policies of many countries related to the challenges of access to non-renewable resources.

The activities indicated in the CE roadmap are grouped as indicated in Table 2. In the area of creating conditions for the development of bioeconomy, they include:

a Establishing a permanent team of directors of departments and ministries who will be responsible for specific areas of bioeconomy operation and appointing a coordinator of this group responsible for defining and supervising activities towards bioeconomy development, which will contribute to a faster information flow between the parties involved. Initially indicated areas of the group's activities should be biomass for energy purposes, food, waste, forestry, greenhouse gases, water resources, industry, innovation, and science. At the beginning of its activity, the team should prepare a report on the framework for the implementation of activities favorable to the bioeconomy.

b Comprehensive analysis of the applicable norms and legal regulations concerning biomass, to create a uniform policy for it, putting particular emphasis on clarifying its definition and scope. The aim of the action is also to propose regulatory changes that will lead to the definition and unification of standards for biological raw materials, which can increase the possibility of their use and thus increase innovation and production in the field of bioeconomy.

c Detailed estimation of the supply of biomass that can be used in the economy. The proposed action in this area includes the development of appropriate methodology at the national and regional level, which can clearly present the available amount of biomass that can be obtained in Poland from each source (agriculture, forestry, fisheries, bio-waste).

d Increasing the collaboration between various groups of stakeholders and the comprehensive analysis of priorities in the areas of research, development and innovation ( $R \& D \& I)$ so as not to omit any significant aspects related to the above-mentioned spheres in the support instruments.

In the area of building local value chains and a raw material base, the specific action focuses on:

a Detailed analysis of economic volumes of biomass (supply, demand, outlets) as well as possible markets for agricultural products derived from biomass, key local value chains with the greatest development potential will be identified.

b Identification of the local value chains, which should be conducted based on the economic and technical capabilities supporting the creation and development of biorefineries. They should enable the production of new products from biomass or the consolidation of many value chains in one industrial plant. This may contribute to maximizing the use of the potential of biomass resources as well as achieving the highest possible profitability of the project.

c Preparation of a feasibility study on the creation and development of biorefineries, taking into account the local and regional conditions.

d Development of an information campaign addressed to people working in agriculture (farmers and other) is to expand their knowledge about activities carried out within the circular economy.

In the area of the energy sector, the following tasks were proposed:

a Development of an information campaign on the principles of cascading use of biomass to deepen the community's knowledge of the need for multiple use of biomass in production processes as well as obtaining energy and fuels from the remaining biomass, for which, taking into account environmental and economic considerations, other usage are not optimal. The campaign should also cover the examples of good practices on recovery of resources and energy from biowaste.

b Detailed analysis of technical and non-technical barriers to the use of advanced biofuels in transport will allow estimating the domestic production and use of these biofuels in line with the transport targets set out in Directive 2009/28/EC and the development of low-emission transport, as well as determining the period in which the internal combustion engine will cease to be used as a vehicle propulsion source. 
The last group includes actions aimed to transformation towards CE in industry:

a Development of an information campaign on products made from biomass, which aims to stimulate demand by presenting relevant facts about bioproducts and thus convince consumers that products derived from biomass may be of the same or better quality than goods made from non-renewable raw materials while minimizing the negative impact on the environment.

b Drawing up standards for individual groups of products derived from biomass may contribute to the improvement of consumer confidence in products made of biomass, e.g., compost or other organic fertilizers.

c Development of an information platform with current biomass statistics (quantity, quality, places of origin, sources of origin: agriculture, forestry, fisheries, biowaste). The information provided on the platform should be easily accessible for entities interested in information on the possibility of obtaining biomass having specific parameters. Taking into account the environmental considerations, biomass should not be transported over long distances. Suppliers and customers should be in the same region.

d Establishment of a working group to develop a concept and create a cluster for the development of the bioeconomy in the known business to business (B2B) model, taking into account the inter-sectoral and regional policy (Polish Roadmap, 2019).

The responsible units and the timetable of the implementation of the specific tasks are indicated in Table 2. The most important unit responsible for the implementation of the CE roadmap in Poland is the Ministry of Development, which was the initiator of the CE roadmap development. However, without the involvement and support of other ministries in Table 2, as well as other stakeholders (such as entrepreneurs, scientists and consumers), the CE model has no chance of successful implementation.

\section{Sources of biomass in Poland}

According to the Polish CE roadmap, the management of renewable resources plays a special role in the development of bioeconomy. One of the most important sources of renewable resources in Poland is the agricultural production, which is used primarily for food, industrial and energy purposes, in particular for direct combustion, and (to a lesser extent) for the production of liquid fuels. In 2018, the agricultural land (wheat, barley, oats, potatoes, colza, vegetables and fruit) in Poland was $14,669,023 \mathrm{ha}$, which is $89.4 \%$ of the total area of farms (GUS, 2019b). This creates great opportunities for the development of a bioeconomy based on this biomass, which is the most common source of renewable energy in country (Polish Roadmap, 2019).

Bioeconomy is an industry based on raw materials of natural origin and biotechnology. Currently, besides the aforementioned food production, biomass is most often used for energy purposes. The structure of primary energy production from renewable sources in 2018 in presented in Fig. 1. In Poland, as much as $69.3 \%$ of green energy is obtained from solid biofuels, i.e., from the co-combustion of biomass (wood) with coal in heat and power plants and power plants. Comparing the data with that of 2017, it is noted that this share is growing (in 2017, the share was $67.7 \%$ ), which suggests that its value may continue to grow in the coming years (GUS, 2020).

Fig. 1. Structure of primary energy production from renewable

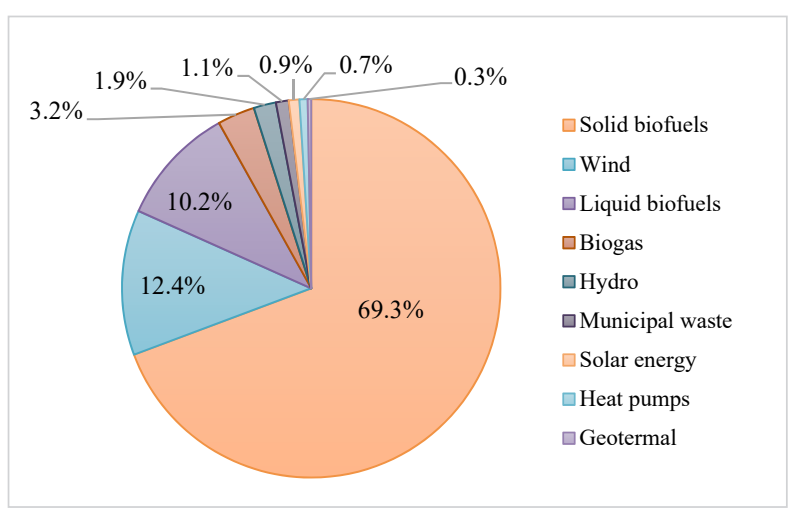

sources in 2018 (GUS, 2020)

The structure of household energy consumption in 2018 is presented in Fig. 2. The share of bioenergy consumed by households in Poland per capita is $13.4 \%$ and is higher than in 2017 by $0.3 \%$ (GUS, 2019a).Nevertheless, the largest share of electricity generated in households comes from the combustion of hard coal (32.3\%), followed by heat obtained from the grid (19.4\%) (GUS, 2020). This creates reasons for the continuous promotion and dissemination of knowledge on the use of biomass as a source of clean energy. 
Fig. 2. Structure of household energy consumption per 1 inhabitant in 2018 (GUS, 2020)

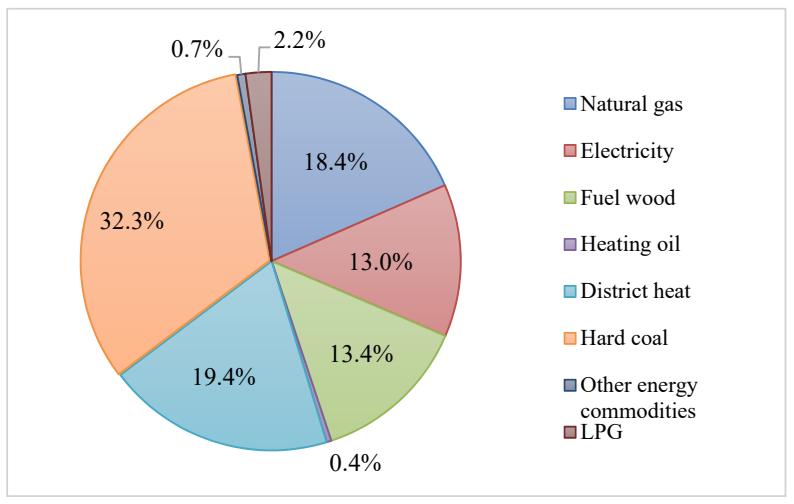

The high share of agricultural land in the total area of the country translates into a large biomass potential. Looking cross-sectionally, domestic resources are the most abundant in solid biomass, which includes among others waste wood from forests and straw (Biomass, 2020). In Poland, most biomass is obtained mainly from agriculture, followed by forestry, which includes wood production, but also has a recreational function, followed by horticulture and the wood industry, as indicated in Fig. 3.

Fig. 3. Structure of the acquisition of biomass in Poland, 2015 (Wyszomierski et al., 2017)

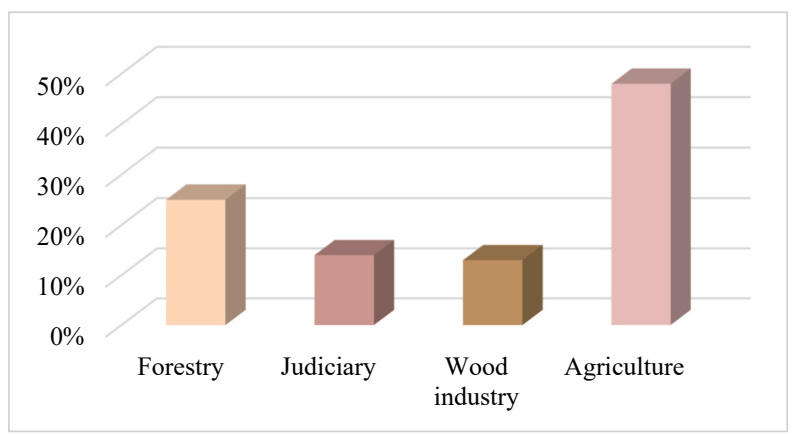

Conscious management of biomass should be paid to the principle of cascading use, in which it is propagated to be used first of all for food production and as a raw material for the pharmaceutical, chemical, paper, construction and organic fertilizer industries. The remaining wastes from these industries should be (if possible) recycled, and biomass residues and discards from the final stages of recycling should be intended for energy purposes, primarily for the production of biofuels and biogas. It is necessary to minimize the technology of direct combustion of residual biomass in favor of their subsequent use for more advanced biofuels, which can become an alternative to fossil fuels. It is also necessary to ensure proximity to the place of biomass production and use in local facilities to reduce emissions associated with the transport of raw material. There is a need to develop domestic production of specialized biofuels for transport, i.e., produced from raw material that is not in direct competition with food crops (Polish Roadmap, 2019). Increasing the level of biomass utilization may also increase employment in agricultural areas. Moreover, it may enable the achievement of the objectives of the European Parliament and Council Directive 2009/28/EC of 23 April 2009 on the promotion of the use of energy from renewable sources, amending and subsequently repealing directives 2001/77/EC and 2003/30/EC (Directive 2009/28/EC, 2009).

Due to the local nature of biomass, creating favorable conditions for its use requires a coherent approach not only at the central but also at the regional level, and the available types of biomass in a given region should specify the directions of its use. Biorefining based on the use of biological and thermal technologies as well as enzymatic conventions for biomass shaping (comparable in some oil refining approaches) can become a way of extracting biomass potential in Poland (Polish Roadmap, 2019). The key activities are also those related to the protection of the raw material base, which is primarily associated with soil resources. In such circumstances, it is important to ensure the quality and availability of soils, e.g., by rational use of mineral and organic fertilizers, or plant protection products (Polish Roadmap, 2019).

The use of biomass in the industry sector is associated with biotechnology, which is considered by the EC as one of the key technologies conducive to further economic development of European countries. Its use makes it possible to replace mining (non-renewable) raw materials, including both energy and non-energy raw materials, with raw materials from renewable sources (biomass) in the production of existing goods. The biodegradability and ease of recirculation of uncontaminated biomass allows it to be used as a raw material in the industry sector, which reduces the level of harmful emissions to the environment in the overall life cycle of the raw material. An additional advantage of industrial biotechnology is its lower price compared with processes based on chemical synthesis (Polish Roadmap, 2019). 


\section{Discussion and Conclusions}

Bioeconomy is one of the most important sectors of implementing the CE model in Poland. Poland has very large resources of biomass, which is the basis for the further development of the bioeconomy. However, the production of innovative materials and products that fit within the bioeconomy requires guaranteeing the continuity of supplies of certain biomass quality. For this reason, local value chains should be built focusing on the areas around locally occurring biorefineries. In this aspect, bioeconomy is a great opportunity for the development of local communities in rural communes. Cooperation between specific entities within value chains can create new, financially attractive jobs (Polish Roadmap, 2019).

The bioeconomy can become an incentive to stimulate innovation and competitiveness of selected industries, such as pharmaceutics, in which biopharmaceuticals with a high added value can be created, reducing invasive medical procedures or streamlined processes related to waste recycling (Polish Roadmap, 2019). In Poland, bioprocesses are used to obtain optically active amino acids, alcohols, carboxylic acids, specific biopolymers, vitamins, and antibiotics. More importantly, an increasing number of cosmetics companies have begun to use renewable biological raw materials to produce their cosmetics. At this plane, new enterprises (usually small) are created, which locally produce cosmetics and detergents. Meanwhile, the pulp and paper industry produces paper using wood biomass. Many universities in Poland also offer specializations in the field of bioeconomy or industrial biotechnology, which may result in the future qualified staff (Polish Roadmap, 2019).

Nevertheless, the use of the bioeconomy potential will not occur itself; it requires the implementation of systemic changes in many sectors, development of strategies, investments as well as innovative ideas. This means that increasing the capacity to seize opportunities that have been initiated through innovative products will translate into the creation of new jobs at the local level, while maintaining profitability and giving priority to issues related to circular economy and sustainable development. Increased impact of research and innovation is key in this context (COM no. 306, 2018).

It should be underlined that the bioeconomy is a key part of the new EU strategy, which is the European Green Deal
(COM no. 640, 2019). The main goal of the EU Green Deal is to meet the challenges of climate change and environmental degradation. To cope with this, the EU adopted this new strategy, thanks to which the economy shall gain such features as resource efficiency, innovation and competitiveness. The most important goals of the EU Green Deal are the zero net greenhouse gas emission threshold by 2050; decoupling of wearing natural resources from economic growth; improvement of the protection and increase of natural capital; inclusion of all persons and regions.

Summarizing, the main conclusions from the current work are the following:

a Bioeconomy activities are one of the key areas for the implementation of CE in Poland in the coming years.

b The strategic activities focused on the CE implementation in the bioeconomy include actions in the field of creating conditions for the development of bioeconomy, building local value chains and a raw material base, energy and industry.

c The management of renewable resources plays a special role in the development of bioeconomy. In Poland, the most important source is biomass coming from agricultural production.

d Integration of actions that have to be taken by various stakeholders (as ministries, industry, science, customers) is required, and further efforts are planned to move towards CE in the bioeconomy sector in Poland.

\section{Acknowledgements}

This work was funded by the Polish National Agency for Academic Exchange (NAWA) as the part of the project Monitoring of water and sewage management in the context of the implementation of the circular economy assumptions (MonGOS) within the International Academic Partnerships Programme (2020-2022, project no. PPI/ APM/2019/1/00015/U/00001/ZU/00002). The founder had no role in the design of the study; in the collection, analysis, or interpretation of data; in the writing of the manuscript, or in the decision to publish the results. 


\section{References}

Adamowicz, M. (2017) Biogospodarka: koncepcja, zastosowanie i perspektywy. Zagadnienia Ekonomiki Rolnej, 1: 29-49. https://doi.org/10.5604/00441600.1232987

Bartoszczuk, P. (2014) Perspektywy rozwoju biogospodarki. Zeszyty Naukowe Wyższej Szkoły Humanitas w Sosnowcu. Zarządzanie, 1: 357-364.

BECOTEPS (2010) Bio-Economy Technology Platforms.

Biomass (2020) Available online: Energetyka24.com/biomasa--wciaz-niewykorzystana-szansa-dla-polskiego-coalstate (accessed on 10 August 2020).

Chyłek E. K., and Rzepecka M. (2011) Biogospodarka konkurencyjność i zrównoważone wykorzystanie zasobów 3-13.

Cologne Paper (2007) En Route to the Knowledge-Based Bio-Economy. German Presidency of the Council of the EU: Cologne, Germany.

COM no. 306 (2018) Odnowiony europejski program na rzecz badań i innowacji - szansa Europy na ukształtowanie własnej przyszłości. European Commission, Brussels.

COM no. 398 (2014) Towards a circular economy: A zero waste programme for Europe. European Commission, Brussels.

COM no. 60 (2012) Innowating for Sustainable Growth: A Bioeconomy for Europe. European Commission, Brussels.

COM no. 614 (2015) Closing the loop - An EU action plan for the Circular Economy. European Commission, Brussels.

COM no. 640 (2019) The European Green New Deal. European Commision, Brussels.

COM no. 673 (2018) A sustainable Bioeconomy for Europe: Strengthening the connection between economy, society and the environment. European Commission, Brussels.

COM no. 98 (2020) A new Circular Economy Action Plan for a cleaner and more competitive Europe. European Commission, Brussels.

Department Environment Food and bio-based products (DEFRA) (2007). UK Biomass Strategy. White Policy Paper, London.

DG Research (2005) New perspectives on knowledge based bio-economy.

DG Research (2006) Food, Agriculture, Fisheries and Biotechnology.

Directive 2009/28/EC of the European Parliament and of the Council (2009) Renewable energy directive. European Wind Energy Conference and Exhibition 2009.
European Commission (EC) (2010) A Bioeconomy for Europe.

European Circular Economy Stakeholders Platform (ECESP), Available online: Circulareconomy.europa.eu/platform (accessed on: 7 August 2020).

Enriquez, J. (1998) Genomics and the world's economy. Science, 281(5379). https://doi.org/10.1126/science.281.5379.925

European Plant Science Organisation (EPSO) (2011). The European Bioeconomy in 2030: Delivering Sustainable Growth by addressing the Grand Societal Challenges.

Gołębiewski, J. (2013) Zrównoważona biogospodarka - potencjat i czynniki rozwoju. IX Kongres Ekonomistów Polskich, 2.

GUS (2019a) Energia 2019.

GUS (2019b) Użytkowanie gruntów i powierzchnia zasiewów w $2018 \mathrm{r}$.

GUS (2020) Energia 2020.

Kowalik, P. (2003) Wykorzystanie biomasy jako surowca energetycznego. Termochemiczne przetwórstwo węgla i biomasy, 39-41.

Maciejczak, M. and Hofreiter, K. (2013) How to define bioeconomy? Roczniki Naukowe, tom XV(4): 243-248.

Martinez J. (1998) Genomies and the world's economy. Science Magazine 281:(5379). https://doi.org/10.1126/science.281.5379.925

McCormick K., Kautto, N. (2013) The Bioeconomy in Europe: An Overvie. Sustainability (Switzerland) 5(6): 2589-2608. https:// doi.org/10.3390/su5062589

Organisation for Economic Co-operation and Development (OECD) (2009) Bioeconomy to 2030: Designing a Policy Agenda. Main Findings, Paris.

Polish Roadmap (2019) Polish Roadmap for Transformation Towards a Circular Economy. Ministry of Development.

Smol, M. et al. (2020) Transformation towards circular economy (CE) in municipal waste management system: Model solutions for Poland. Sustainability (Switzerland): 12(11). https://doi. org/10.3390/su12114561

The White House (2012) National Bioeconomy Blueprint, Washington.

Wyszomierski, R. et al. (2017) Spatial Diversification of Biomass Production in Poland. Annals of the Polish Association of Agricultural and Agribusiness Economists XIX(2): 282-288. https:// doi.org/10.5604/01.3001.0010.1219 